\title{
Water Pollution Index (WPI) and Incidence of Diarrhea Among Children Under Five Years Old in Coastal Area of Semarang City, Indonesia
}

\author{
Fatimatuzzahro $^{1 *}$, Mursid Raharjo $^{2}$, Nurjazuli ${ }^{3}$ \\ ${ }^{1}$ Environmental Health Department, Faculty of Public Health, Diponegoro University \\ ${ }^{2}$ Magister Programme of Environemetal Health, Diponegoro University \\ ${ }^{3}$ Public Health Faculty, Diponegoro University
}

\begin{abstract}
Coastal area of Semarang City is susceptible to water pollution and one of which is due to sea water intrusion. Diarrhea is an infectious disease that causes more than $26,93 \%$ of mortality in children under five years old and cases average over $30 \%$ in coastal area of Semarang City. The aim of this study was to evaluate assotiation between Water Pollution Index (WPI) and incidence of diarrhea in children under five years old. This type of research is an observational analytic study with a cross sectional study design. Sampel consisted of 18 respondens from 7 districts in coastal area of Semarang City. Independent variable is water pollution index which is calculated based on parameters of $\mathrm{pH}$, salinity, TDS, and E.coli. Dependent variable is incidence of diarrhea under five years old. Data analysis used univariate and bivariate analysis using rank spearman correlation and Geographical Information System (GIS). Result found moderate category of water pollution index in Mangkang Kulon, Mangunharjo, Mangkang Wetan, and Bandarharjo. We identified associations between water pollution index (p 0,014, r: 0,857), E.coli in water (p 0,017, r: 0,842), salinity in water (p $0,013, \mathrm{r}: 0,860)$, TDS in water (p $0,011, r: 0,871)$ and incidence of diarrhea. There is no relationship significantly between $\mathrm{pH}$ in water $(\mathrm{p} 0,782, \mathrm{r}:-0,130)$ and incidence of diarrhea. WPI provides information on water quality and contaminants in water has potential trigger to digestive disorders. Cases of diarrhea occured by pathogenic microbiological, material, and chemical compounds. Conclussion, there is assotiation between water pollution index and incidence of diarrhea in coastal area of Semarang City.
\end{abstract}

Keywords. water pollution index, diarrhea, Semarang City

* Corresponding author: fatimatuzzahro12@students.undip.ac.id 


\section{Background}

Clean water is a fundamental human right because its related to the right of life of a person. In the world, 780 million people do not have access to an improved water source. The UN Declaration of Human Right of Water states that human right regarding water are needed to guarantee all forms of life, especially humans [1]. The Sustainable Development Goals (SDG's) agenda consists of 17 goals, the sixth goal is to guarantee the availability of clean water and sustainable hygiene and sanitation for people [2]. The coastal area of Semarang City has problem in finding availability of clean water and drinking water for coastal residents. The availability of clean water is closely related to the population condition. Coverage of clean water in Semarang City is not $100 \%$ because the production capacity of PDAM Semarang is only $2.500 \mathrm{~m}^{3} /$ second. Ideally the PDAM should be able to offer 3.500 $\mathrm{m}^{3} /$ second. Meanwhile ground water with good quality is only found at a depth of 80 meters [3]. Decline in water quality in the coastal areas is partly due to industrial activities, settlements, ports, tourism and others.

Data of Semarang City environmental inventory study on October 2018, regarding ground water quality and surface water quality in Semarang City found several parameters that were below the quality standard based on Permenkes No.492 of 2010 concerning Drinking Water Quality Requirements. Based on the results of the calculation of Water Pollution Index (WPI), it can be seen the status of water quality in the coastal area of Semarang City. The result is Genuk District suffered heavy pollution, Tugu and North Semarang District suffered medium pollution, and West Semarang District suffered mild pollution [4].

Safely managed water, hygiene, and sanitation services are an important step towards disease prevention. Biologically, physically, and chemically contaminated water can be the cause of a disease. Diarrhea is an infectious disease cause by contaminated water. In 500 households in Bangladesh found that every 10-fold increase in Eschericia coli contamination in drinking water was associated with $16 \%$ increase in diarrhea [5]. More than $26.93 \%$ diarrhea related-mortality occur in children under five years old. In Semarang City, cases of diarrhea on 2018 were 50.021 and the largest number of cases were in children group by 33.195 cases. In coastal area of Semarang City, diarrhea data on JulySeptember 2019, diarrhea cases in Bandarharjo Health Center were 266 cases and 35.3\% (94 cases) were cases of diarrhea in children, Genuk Health Center were 28 cases and $67.8 \%$ (19 cases) were cases of diarrhea in children, Mangkang Health Centers were 191 cases and $41.8 \%$ (90 cases) were cases of diarrhea in children, Karanganyar Health Centers were 109 cases and 38.5\% (42) were cases of diarrhea in children, and Krobokan as many as 42 cases and 19\% ( 8 cases) were cases of diarrhea in children. Based on the data above, diarrhea cases in children are above $30 \%$ on average [6].

Clean water quality data is calculated by Water Pollution Index (WPI) and interpreted using a table and then spatially analyze using a Geographic Information System (GIS). Spatial approach is considered effective to describe state spreading of diarrheal disease. From this background, this study aims to determine the relationship between Water Pollution Index (WPI) and incidence of diarrhea among children under five years old in coastal area of Semarang City. The study sites were in three districts consisting of seven sub-districs in coastal area of Semarang City. 


\section{Method}

Location of this study are Tugu which consists of Mangkang Kulon, Mangunharjo, and Mangkang Wetan Sub-Districts. West Semarang which consists of Tambakharjo and Tanjungmas Sub-Districts. North Semarang which consists of Bandarharjo and Tawangmas Sub-Districts. Research period starts from March to May 2020. Population in this study is groundwater from artesian or dug wells in seven sub-districts and children who suffered diarrhea in 2019 and recorded in the coastal health centers of Semarang City, which are Mangkang Health Center, Lebdosari Health Center, and Bandarharjo Health Center. Samples of this study are groundwater from 3 points in seven sub-districts and 18 respondents are shown in figure 1. Sampling in this study using purposive sampling method.

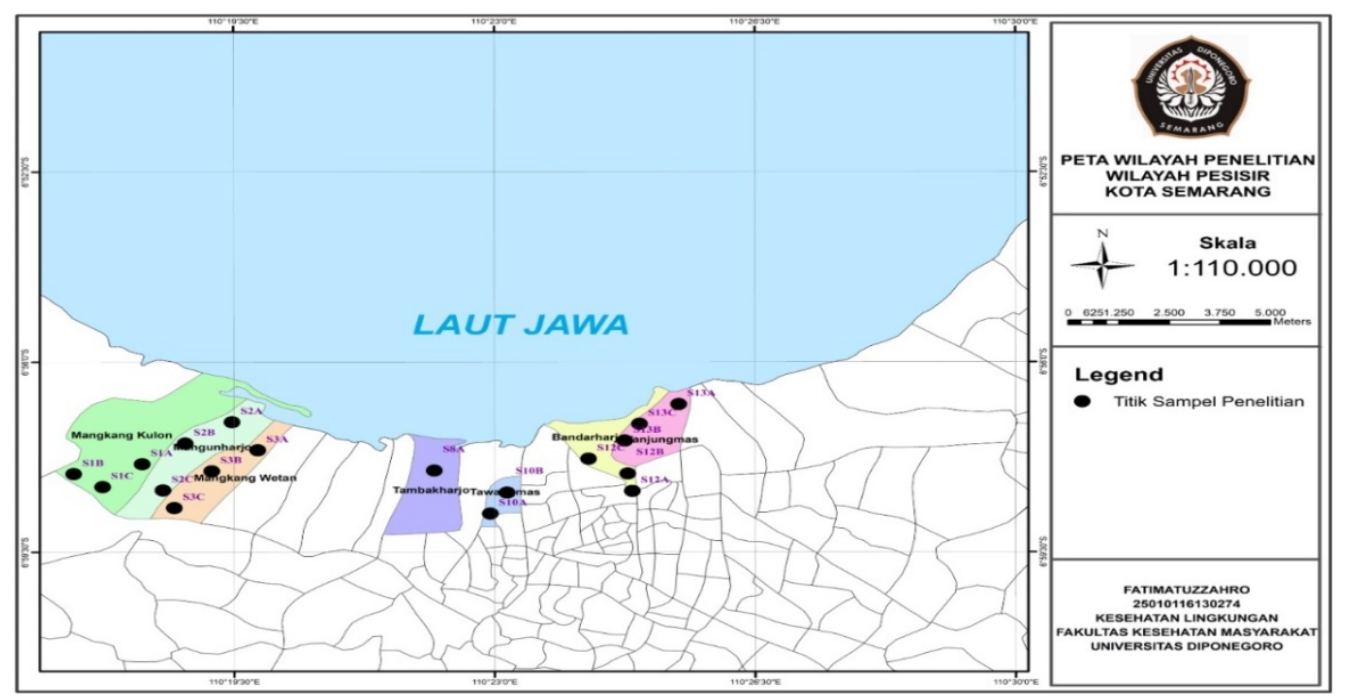

Fig. 1. Point of sampels area mapping

Type of research is observational analytic with cross sectional study design. Independent variable in this study is the Water Pollution Index (PI) which is mwansured based on parameters of Ph, TDS, salinity and E.coli according to the Decree of the Minister of the Environment No.115 of 2003, E.coli with following eqution:

$$
\mathbf{P I}_{\mathrm{j}}=\sqrt{\frac{\left(\mathrm{C}_{\mathrm{i}} / \mathrm{L}_{\mathrm{ij}}\right)_{\mathrm{M}}^{2}+\left(\mathrm{C}_{\mathrm{i}} / \mathrm{L}_{\mathrm{ij}}\right)_{\mathrm{R}}^{2}}{2}}
$$

which $P i j$ is pollution index for designaton $j, C i$ is concentration of water parameters, $L i j$ is concentration of water quality parameters in quality standards, $M$ is maximum value, and $R$ is mean. Categorization of level pollution is $0 \leq \mathrm{IPj} \leq 1$ (quality standards), $1 \leq \mathrm{IPj} \leq 5$ (lightly polluted), $5 \leq \mathrm{IPj} \leq 10$ (moderatelt polluted), and $\mathrm{Ipj}>10$ (heavily polluted). E.coli parameter was meansured using membrane filter method, $\mathrm{pH}$ was measured according to SNI 066989-11-2004, TDS and salinity were measured with TDS meter. All parameters were tested at Semarang City Health Laboratory. Dependent variable was incidence of diarrhea measured using the incident formula, ie the number of new cases of diarrhea in children divided by the total population of children in 2019 per-1000 children. There are confounding variables, among others: feces disposal facilities, waste disposal facilities, and waste water disposal facilities. 
This research uses primary data and secondary data. Primary data are water quality measurements and interviewing respondent to collect data on factors causing diarrhea and hygiene-sanitation facilities. Secondary data are number of cases of diarrhea and population of children under five years old. Data were calculated, processed, and analyzed using SPSS through editing, coding. scoring, entry, and tabulating. Data analysis uses the Rank Spearman Correlation test to identify relationships between variables and Spatial analysis uses ArcGIS.

\section{Results}

\subsection{Characteristic of Respondens}

Characteristic of respondents in this study had large age distribution with the age of 4 years $(27.8 \%)$ and respondents aged 3 years $(22.2 \%)$. While the percentage of respondents aged 1 year, 2 years, and 5 years are $16.7 \%$. In sex distribution with the largest percentage is male $(66.7 \%)$. In the category of diarrhea, the largest percentage of diarrhea was acute diarrhea $(88.9 \%)$ and without dehydration $(77.8 \%)$.

\subsection{Measurement Results of Ground Water Parameters}

Parameters to be tested consist of $\mathrm{pH}$, salinity, TDS, and E.coli. Based on table 1 the results of the measurement of groundwater $\mathrm{pH}$ produce an average $\mathrm{pH}$ value of 7.45 with a standard deviation value of 0.35 . Maximum value of the $\mathrm{pH}$ measurement is 8.41 and the minimum value is 7.03 . These results indicate that all groundwater samples $(100 \%)$ have a $\mathrm{pH}$ value that meets the quality standards based on Permenkes No.31 of 2017, which is 6.58.5 .

Table 1. Frequency Distribution of Parameter Measurement Results

\begin{tabular}{llllllll}
\hline Parameter & $\mathrm{F}(\mathrm{MS})$ & $\%$ & $\mathrm{~F}(\mathrm{TMS})$ & $\%$ & Min & Max & Mean \\
\hline $\mathrm{pH}$ & 18 & 100 & 0 & 0 & 7.03 & 8.41 & 7.45 \\
Salinity (mg/l) & 10 & 55.6 & 8 & 44.4 & 78.4 & 1939 & 515,56 \\
TDS (mg/l) & 16 & 88.9 & 2 & 11.1 & 82.4 & 1833 & 513.2 \\
E.coli $(\mathrm{CFU} / 100 \mathrm{ml})$ & 8 & 44.4 & 10 & 55.6 & 0 & $<200$ & - \\
\hline
\end{tabular}

In measurement of salinity, average of salinity value is $515.56 \mathrm{mg} / \mathrm{l}$ with a standard deviation of $436.9 \mathrm{mg} / \mathrm{l}$. Maximum salinity measurement is $1939 \mathrm{mg} / \mathrm{l}$ and minimum value is $78.4 \mathrm{mg} / \mathrm{l}$. Salinity measurement results showed 8 samples $(44.4 \%)$ did not meet the quality standard according to Permenkes 492 of 2010, which was $500 \mathrm{mg} / \mathrm{l}$. In TDS measurements, the average TDS value was $513.2 \mathrm{mg} / \mathrm{l}$ and median was $468 \mathrm{mg} / \mathrm{l}$ with a standard deviation of $412.73 \mathrm{mg} / \mathrm{l}$. Maximum value of TDS measurement is $1833 \mathrm{mg} / \mathrm{l}$ and the minimum value is $82.4 \mathrm{mg} / \mathrm{l}$. Based on these results, there were 2 samples $(11.1 \%)$ that did not meet quality standard and as many as $16(88.9 \%)$ samples met quality standard according to Permenkes No. 32 of 2017 , which amounted to $1000 \mathrm{mg} / \mathrm{l}$. In measurement of E.coli ground water produces a maximum value of E.coli values of more than $200 \mathrm{CFU} / 100$ $\mathrm{ml}$ and a minimum value of $0 \mathrm{CFU} / 100 \mathrm{ml}$. Based on these results, 10 samples $(55.6 \%)$ did not meet quality standard and as many as $8(44.4 \%)$ samples met quality standard according to Permenkes No.32/2017, which is equal to $0 \mathrm{cfu} / 100 \mathrm{ml}$. 


\subsection{Overview of Water Pollution Index}

Determination of water quality status using Water Pollution Index (WPI) Method in accordance with Decree of the Minister of Environment No.115 of 2003. Based on calculation of WPI values in figure 2, the status of ground water quality in three subdistricts $(42.9 \%)$ is in accordance with quality standard, namely Tambakharjo (WPI value: 0.73 ), Tawangmas (WPI value: 0.95), and Tanjungmas (WPI value: 0.86). A total of four sub-districts $(57.1 \%)$ with moderate polluted results, namely Mangkang Kulon (WPI value: 9.23), Mangunharjo (WPI value: 9.26), Mangkang Wetan (WPI value: 9.22), and Bandarharjo (WPI value: 5.81).

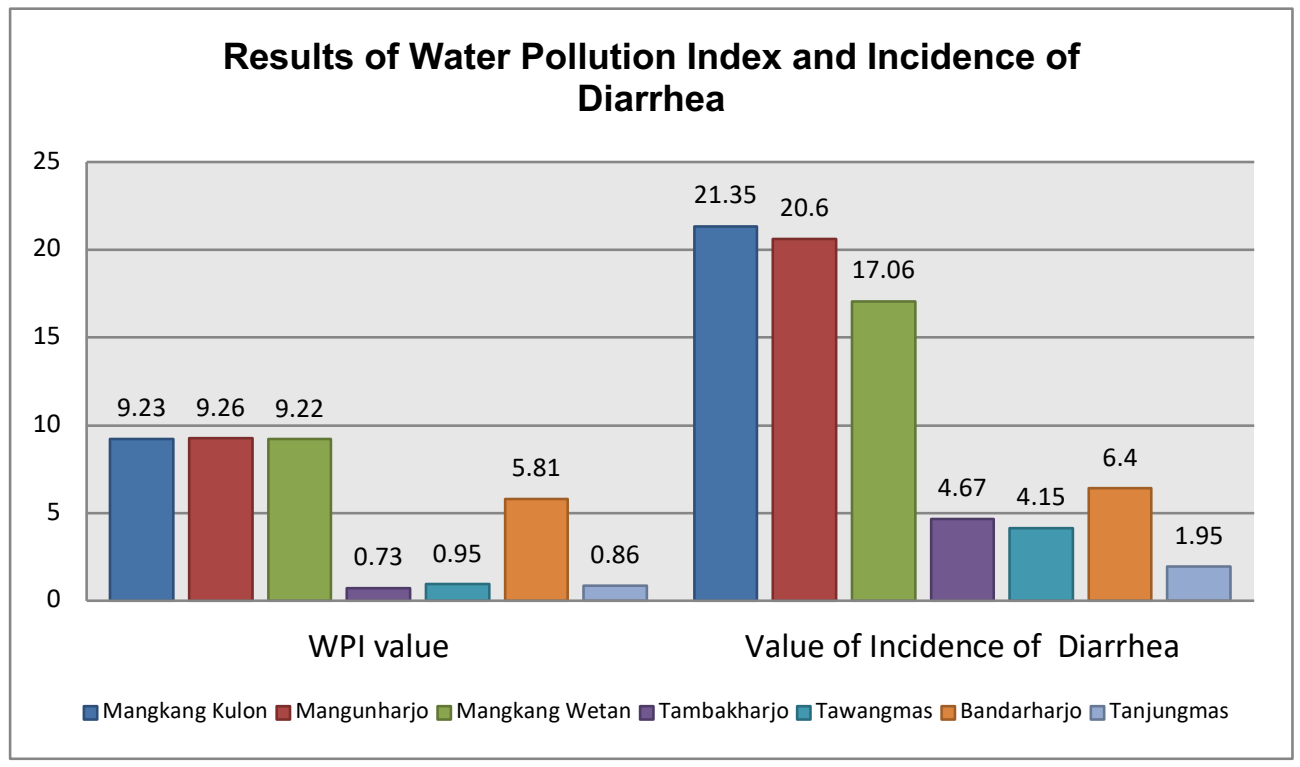

Fig. 2. Chart of Results of Water Polluon Index and Incidence of Diarrhea

The results of calculation of the pollution index (WPI) value, it can be seen the status of ground water quality in 7 sub-districts in coastal area of Semarang has decreased, this is indicated by water pollution values of mild to moderate pollutants. Based on these results, the quality of ground water in 7 sub-districts in coastal area of Semarang City cannot be used as drinking water. In addition, according to Permenkes No.492 of 2010 concerning Drinking Water Quality Requirements, it states that water used or consumed must be free of microbiological content.

\subsection{Overview of Incidence of Diarrhea in Choldren Under Five Years Old}

Incidence of diarrhea in children in coastal area of Semarang City is number of new cases of diarrhea in children under five years old during 2019 so data on population of children and number of diarrhea cases are needed. Total population of children under-fives is 5186 children. The highest population is in Tanjungmas with 2259 children under five while the lowest is in Tambakharjo with 107 children. The highest number of diarrhea sufferers in Bandarharjo as many as 99 children and the lowest was in Tambakharjo as many as 5 children. In other sub-district the number of diarrhea others are Mangkang Kulon was 60 children, Mangunharjo as many as 75 children, Mangkang Kulon as many as 72 children, Tawangmas as many as 9 children, and Tanjungmas as many as 44 children. All diarrhea 
and population data were obtained from community health centers around coastal area of Semarang City.

The highest incidence of diarrhea among children under five years old is in Mangkang Kulon Village with 21.35 cases per-1000 children while the lowest is in Tanjungmas Village with 1.95 cases per-1000 children. Incidence value of diarrhea in other sub-districts are Mangunharjo with 20.6 cases per-1000 children; Mangkang Wetan eith 17.06 cases per1000 children; Tambakharjo with 4.67 cases per-1000 children; Tawangmas with 4.15 cases per- 1000 children; and Bandarharjo with 6.4 cases per- 1000 children. Incidence value of diarrhea in infants is then categorized. In this study determination of category of diarrhea incidence variables in children using descriptive statistics analysis $X$ min (1.95), $X$ max (21.35), mean (10.87), range (19.4), and standard deviation (3.23). Variable incidence of diarrhea is categorized into three namely high, moderate, and low. Based on the results of categorization, incidence of children with high category of diarrhea is found in Mangkang Kulon, Mangunharjo, and Mangkang Wetan. Whereas for the low category there are in Tambakharjo, Tawangmas, Bandarharjo, and Tanjungmas.

\subsection{Overview of Hygiene Sanitation Facilities}

Variables of sanitary hygiene water conditions, feces disposal facilities, and water waste disposal facilities were measured using interview and observation methods with 8 questions asked to respondents. As for variable means of water waste disposal, measured using interview and observation methods with 7 questions asked to respondents. These variables are categorized into three namely good, moderate, and using statistical analysis of X min, $\mathrm{X}$ max, mean, range, and standard deviation.

Table 2. Frequency Distribution of Hygiene Sanitation Facilities

\begin{tabular}{cccc}
\hline Variables & $\begin{array}{c}\text { Good } \\
(\%)\end{array}$ & $\begin{array}{c}\text { Moderate } \\
(\%)\end{array}$ & $\begin{array}{c}\text { Bad } \\
(\%)\end{array}$ \\
\hline Water for hygiene sanitasi & 16.7 & 72.2 & 11.1 \\
Feces Disposal & 55.5 & 16.7 & 27.8 \\
Waste Disposal & 38.9 & 27.8 & 33.3 \\
Water Waste Disposal & 44.4 & 38.9 & 16.7 \\
\hline
\end{tabular}

In water for sanitation hygiene condition variable, most of respondents have good sanitation hygiene water condition. Respondents who have clean water are tasteless $(77.8 \%)$, colorless $(100 \%)$, and odorless $(88.9 \%)$. Respondents who did not use clean water for drinking $(88.9 \%)$, did not use clean water to wash food $(0 \%)$, and did not use clean ar for toothbrushes $(0 \%)$. Respondents who did groundwater treatment before use $(44.4 \%)$ and distance of water source to septic tank was more than $10 \mathrm{~m}(55.6 \%)$. Categorization results show that biggest percentage, namely sanitary hygiene water condition, was sufficient at $72.2 \%$. Good category is $16.7 \%$ and bad category is $11.1 \%$. In feces disposal facilities, respondents who have latrines are $100 \%$. Condition of floor and wall latrines is not slippery $(72.2 \%)$, odorless $(88.9 \%)$, clean $(77.8 \%)$, and tight so that no vectors enter $(77.8 \%)$. Respondents who clean latrines 3-3 days (55.6\%). Latrine channel is easy to pour $(100 \%)$ and sufficient water and soap is available (94.4\%). Categorization results show that the biggest percentage is the condition of the good feces disposal facilities (55.5\%). Whereas for moderate category is $16.7 \%$ and bad category is $27.8 \%$.

In waste disposal facilities, most of the respondents have a large portion of good waste disposal facilities. Respondents who have wet garbage dumps are $77.8 \%$ and $88.9 \%$ have proper external garbage disposal. Disposal of garbage does not exceed 2 X24 hours $(5.6 \%)$, there is a lid on the trash $(61.1 \%)$, there are no flies around the trash $(94.4 \%)$. Respondents 
who do waste processing by dumping it into TPS (72.2\%). Respondents who have trash cans made of watertight material $(88.9 \%)$ and trash cans that are easy to transport $(88.9 \%)$. Results of categorization show that the largest percentage is condition of the good category of waste disposal facilities at $38.9 \%$. Meanwhile, moderate category was $27.8 \%$ and bad category was $33.3 \%$ In water waste disposal facility, most of respondents have very good condition. Respondents who have a water waste disposal of $100 \%$. Most respondents have a SPAL distance of more than 10 meters $77.8 \%$. Water waste disposal is closed $(61.1 \%)$, flows smoothly $(77.8 \%)$, does not cause odor $(77.8 \%)$, there is no vector $(88.9 \%)$, and does not cause inundation (88.9\%). Categorization results show that the highest percentage is the condition of the good water waste disposal facility $(44.4 \%)$. As for moderate category was $38.9 \%$ and category was bad $(16.7 \%)$.

\subsection{Bivariate Analysis}

Bivariate analysis in this study was to determine relationship between dependent variable, incidence of diarrhea in children under five years old and independent variables, Water Pollution Index (WPI) also parameters of E.coli, TDS, salinity, and pH. Statistical test used is Rank Spearman Correlation that is because data distribution is not normal.

Table 3. Result of Correlation Between Variables

\begin{tabular}{cccc}
\hline Variables & $\begin{array}{c}\text { p- } \\
\text { value }\end{array}$ & $\begin{array}{c}\text { Koef } \\
\text { Correlation }\end{array}$ & Correlation \\
\hline WPI & 0.014 & 0.857 & Correlate \\
E.coli & 0.017 & 0.842 & Correlate \\
TDS & 0.011 & 0.871 & Correlate \\
Salinitas & 0.013 & 0.860 & Correlate \\
Ph & 0.782 & -0.130 & Un-Correlate \\
\hline
\end{tabular}

Based on table 3 it is known that WPI (p 0.014), E.coli (p 0.017), TDS (p 0.011), and Salinity $(\mathrm{p} 0.013)$ have a significant correlation $(\mathrm{p}<0.05)$ with a very strong correlation strength strong ( $\mathrm{r}$ between 0.0-1.00) and direction of positive correlation, meaning that higher independent variable, higher incidence of diarrhea in children under five years old. Whereas the $\mathrm{pH}$ variable has no significant correlation $\mathrm{p} 0.782(\mathrm{p}>0.05)$.

\section{Discussions}

An increase in population and activities in coastal areas of Semarang City such as settlements, industry, ports, tourism and agriculture indicate a decrease in quality and quantity of ground water. Excessive intake of ground water triggers entry of sea water and mixes with ground water. In addition, coastal area of Semarang City is also included in the red zone, meaning that it needs restrictions on groundwater extraction [7]. Quality of ground water sources is a determinant of quality of stored water and is usually used for daily needs. Results of statistical analysis using the Spearman Rank produced $p$ values of $0.014(\mathrm{p}<0.05)$ which showed that there was a significant correlation between the WPI and incidence of diarrhea. Correlation coefficient value of 0.857 means strength of correlation between the two variables is very strong with the direction of the positive correlation means that higher WPI variable, higher the incidence of diarrhea in children under five years old.

Based on data on incidence of diarrhea the highest in Tugu District, precisely in of Mangkang Kulon Sub-district amounted to 21.35 cases per-1000 children. While the lowest incidence of diarrhea is in North Semarang District precisely in Tanjungmas Sub-district by 1.95 cases per-1000 children. Based on data, 213 children $(58.5 \%)$ were male and 151 
children (41.5\%) were female. Prevalence of diarrhea cases among children under five years old is higher in males than in females. Biological explanation related to fact that boys during infancy must build muscle mass greater than girls. So boys need more micronutrients hence more risk for negative balance, including vitamin A deficiency and zinc. This vulnerability further increases the risk of boys getting infected with diarrhea. Most cases were found in 4-year-old children (27.8\%). This is possible because the sampling technique is different and sample size is different. Greater the age of the child, immune system becomes more resistant to diarrhea agents. Symptoms of diarrhea in older children are also lighter and easier to treat [8].

Based on the calculation of WPI, most of pollution index values are influenced by the E.coli and salinity parameters. Indirectly, two parameters most have a relationship with incidence of diarrhea. Even E.coli number could be higher than $200 \mathrm{CFU} / 100 \mathrm{ml}$ water sample. So it is assumed that WPI value can be greater than value stated. This is evidenced in sub-district that have WPI value according to standard quality of low E.coli numbers only $0-1 \mathrm{CFU} / 100 \mathrm{ml}$ of water samples. Other studies also prove that there is a relationship between poor water quality and diarrhea [9]. This is evidenced from studies show that interventions with improve water quality have been linked to reduction incidence of diarrhea. Interventions with water filtration showed a significant reduction in diarrhea of $53 \%[10]$. Interventions using water disinfection showed a significant reduction of $31 \%$. So it is suggested that impact is greater with water filtration than water disinfection [11].

Fecal contamination is transmitted to the environment through several transmission lines. Human waste in the environment without effective isolation can spread to ground water and waters. Results of statistical analysis using Spearman Rank shows $\mathrm{p}$ values of 0.017 ( $\mathrm{p}<0.05)$ meaning that there was a very strong correlation between E.coli variables with incidence of diarrhea. This is in line with research by Felicia, et al in 2017 stating that out of 50 acute diarrhea subjects 25 subjects $(50 \%)$ were caused by E.coli bacteria[12]. E.coli is one of causes of diarrhea as well as a biological indicator of environmental pollution by feces. Fecal contamination is transmitted to environment through several transmission lines. Contamination pathways can come from soil, hands, ponds, water sources, stored water, flies, and food[13]. DEC (Diarrheagenic Escherichia coli) is E.coli strain that is most often cause of diarrhea in children. DEC is generally found in children aged 1-2 years compared to those aged $<1$ year or 3-5 years. Research conducted in Bangladesh in 2017 yielded 25\% E.coli was found in well water and $77 \%$ in drinking water[14].

TDS is total dissolved solid, the amount of dissolved solids usually minerals, salts, metals, cations or anions and any substances that are dissolved in water. Statistical test results obtained $p$ value $0.011(p<0.05)$ showed that a significant correlation between TDS variables and incidence of diarrhea in children under five years old. Correlation coefficient value of 0.871 means that correlation strength between two variables is very strong with direction of positive correlation meaning higher TDS variable, higher incidence of diarrhea in children. This is consistent with research conducted in Solo watershed there is a relationship between TDS levels in well water with incidence of diarrhea with a value of $p$ $=0.001(\mathrm{p}<0.05)$. Average TDS measurement results based on the results table are 513.2 $\mathrm{mg} / \mathrm{l}$ and median $468 \mathrm{mg} / \mathrm{l}$. Water containing concentrations of TDS below 1,000 mg/1 is usually acceptable but water with very low TDS concentrations is also unacceptable for consumers because of its flat and tasteless taste for consumers [15].

Based on the statistical test $\mathrm{p}$ value of $0.013(\mathrm{p}<0.05)$ indicates that there is significant correlation between salinity with incidence of diarrhea. Correlation coefficient value of 0.601 means strength of correlation between two variables is very strong with direction of positive correlation means higher variable water salinity, higher incidence of diarrhea. This is in accordance with Studies in Bangladesh found an association between increased salt in 
drinking water with diarrhea, dysentery, and digestive disorders. Interestingly, the study also revealed that people who live in areas with low salinity (24\%) have a higher awareness of the dangers of drinking water with high salinity levels [16]. Area with low salinity water have more awareness about health effect of excess salinity in water [17].

Effect of salinity on water that causes diarrhea is directly caused because salinity will affect the growth of E.coli. Low water (rehydration) activity caused by salt has potential to increase microbial growth. Increasing the concentration of $\mathrm{NaCl}$ and $\mathrm{KCl}$ (salt) from $0.5 \%$ to $1.5 \%$ results in increased growth of E.coli. At concentration of Rehydration can cause anoxic environment around bacterial cells so it must overcome activity of water in their environment. Bacteria will adapt by giving the cytoplasmic osmotic balance of cells with a medium salinity. This study only focuses on the quality status of water quality and its parameters, but other factors such as natural immunity, malabsorption, immunodeficiency, allergies, toxicity, and psychological factors can limit individual responses to diarrhea. Therefore more research is needed to explain other factors [18]. High salinity and TDS disturb the body's water/salt balance. Release of organic subtances and salts imposing stress on mechanism of homeostasis. This encourages changes in gastrointestinal muscles and mucosa, so it is become one of factors causing diarrhea.

Statistical test showed a $\mathrm{p}$ value of $0.782(\mathrm{p}>0.05)$ indicating no significant correlation between $\mathrm{pH}$ variable and incidence of diarrhea in children. Correlation coefficient value of -0.130 means direction of negative correlation means $\mathrm{pH}$ value is not directly related to diarrhea but with bacteria that cause diarrhea, one of which is E.coli. $\mathrm{pH}$ has optimum value for bacterial growth. If $\mathrm{pH}$ is too high or too low, most aquatic organisms will not be able to adapt to extreme conditions. $\mathrm{pH}$ value is easy to change depending on environmental conditions, one of which is due to factors is organic matter in water. E.coli survival is influenced by environmental $\mathrm{pH}$. In some strains of E.coli it can withstand a relatively low $\mathrm{pH}$ than a relatively high $\mathrm{pH}$. Survive E.coli has an acid resistance system mechanism that depends on decarboxylase or antipoter to withstand low $\mathrm{pH}$.

\section{Conclusion}

WPI provides information on water quality and contaminants in water has potential trigger to digestive disorders. The highest of incidence of diarrhea Mangkang Kulon amounted to 21.35 cases per-1000 children. While the lowest in Tanjungmas amouted to 1.95 cases per1000 children. Result found moderate category of WPI in Mangkang Kulon, Mangunharjo, Mangkang Wetan, and Bandarharjo. There is a relationship between the index of water pollution with the incidence of diarrhea in infants with $p$ values of $0.014(p<0.05)$.

\section{Recomendation}

Groundwater sources in coastal area of Semarang City cannot be used as a source of drinking water because they experience light to moderate pollution and contain E. coli in accordance based on Permenkes No.492/2010. In addition, groundwater treatment such as filtration or disinfection is required on a household scale before used for daily needs. 


\section{References}

1. United Nation. Realising the human rights to water and sanitation: A Handbook by the UN Special Rapporteur Catarina de Albuquerque. (2011)

2. United Nations. Transforming our world: the 2030 agenda for sustainable development. (2011).

3. Sriyono, Nur Qudus. Model Spasial Ketersediaan Air Tanah dan Intrusi Air Laut Untuk Penentuan Zone. (2017; 87-94).

4. Dinas Lingkungan Hidup. Pengendalian Pencemaran Air Laut oleh Industri di Provinsi Jawa Tengah. (Semarang. 2018).

5. Luby SP, Halder AK, Huda T, et al. Microbiological Contamination of Drinking Water Associated with Subsequent Child Diarrhea. (2015; 93: 904-911).

6. Dinas Kesehatan Kota Semarang. Data Diare Bulan Juli sampai September 2019 di Puskesmas Wilayah Pesisir Kota Semarang. (2019; 1-14).

7. Suhartono E, SurWPIin P. Kondisi Intrusi Air Laut Terhadap Air Tanah Pada Akuifer di Kota Semarang. Proseding Seminar Nasional Pengelolaan Sumberdaya Alam dan Lingkungan. (2013; 396-401).

8. Nwaoha AF, Ohaeri CC, Amaechi EC. Prevalence of diarrhoea, and associated risk factors, in children aged 0-5 years, at two hospitals. Cuad Investigation UNED. (2017; 9: 7-14).

9. Kamaluddin MT, Sriwijaya U, Salni S, et al. Analysis Of Water Quality, Sanitation Facilities With Incidence. Asian Academic Research Journal of MultidisWPIlinary.(2015).

10. Yuhas K, Pavlinac PB, Naulikha JM, et al. Water Filter Provision and Home-Based Filter Reinforcement Reduce Diarrhea in Kenyan HIV-Infected Adults and Their Household Members. American Society Tropical Hygiene Water (2014; 91: 273-280).

11. Mengistie B, Berhane Y, Worku A. Household Water Chlorination Reduces Incidence of Diarrhea among Under-Five Children in Rural Ethiopia: A Cluster Randomized Controlled Trial. (2013; 8: 1-7).

12. Felicia Halim, Sarah M. Warouw, Novie H. Rampengan PSB. Hubungan Jumlah Koloni Escherichia Coli dengan Derajat Dehidrasi pada Diare Akut. Ilmu Kesehatan Anak Fakultas Kedokteran Universitas Sam Ratulangi (2017; 19: 81-85).

13. Peirano V, Bianco N, Navarro A, et al. Diarrheagenic Escherichia coli Associated with Acute Gastroenteritis in Children from Soriano, Uruguay. Journal Infectious Disease Medical Microbiol 101155/2018/8387218 Res (2018; 8: 218).

14. Chakraborty R, Khan KM, Dibaba DT, et al. Health Implications of Drinking Water Salinity in Coastal Areas of Bangladesh. International Journal Environmental Public Health Artic (2019; 16: 1-10).

15. Yuniarno S. Hubungan Kualitas Air Sumur Dengan Kejadian Diare Di Das Solo Program Pasca Sarjana. Kesehatan Lingkungan. Solo. 2015.

16. Rahaman MA, Rahman MM. Impact of Salinity on Infectious Disease Outbreaks: Experiences from the Global Coastal Region. (2020).

17. Chakraborty, Rishika et al. Health Implications of Drinking Water Salinity in Coastal Areas of Bangladesh. International Journal of Environmental Research Publich Health. (2019 Oct:16(19)).

18. Dino Gunawan dan Pryambodo JP. Zonasi Intrusi Air Asin Dengan Kualitas Fisik Air Tanah Di Kota Semarang. Jurusan Fisika FMWPIA Univ Negeri Semarang. (2017; 8996.) 